\title{
Opinions and behavior of family doctors concerning vaccinating against influenza
}

\author{
PIOTR GUTKNECHTA-F, TOMASZ WINIARSKI ${ }^{\mathbf{A}, \mathbf{B}}$, BARTOSZ GABRIEL TRZECIAK ${ }^{\mathbf{B}}$, \\ ANDRZEJ MOLISZC, MAŁGORZATA PIETRZYKOWSKAB', KATARZYNA NOWICKA-SAUERA, \\ JANUSZ SIEBERT ${ }^{\mathrm{D}}$
}

Department of Family Medicine, Medical University of Gdansk

A - Study Design, B - Data Collection, C - Statistical Analysis, D - Data Interpretation, E - Manuscript Preparation, $\mathbf{F}$ - Literature Search, $\mathbf{G}$ - Funds Collection

Summary Background. Influenza is a severe respiratory disease caused by influenza virus. According to estimates from the World Health Organisation (WHO), 5-15\% of the world's population, or 330-1575 million people, suffer from influenza each year. The vaccination of patients and health professionals plays an important role in the prevention of infections.

Objectives. To describe family doctors' opinions and behavior concerning influenza vaccination.

Material and methods. An online survey was filled out by 77 family physicians, of whom women accounted for $53.5 \%$. The age mean of the doctors surveyed was $44.6 \pm 11.7$ years. The questionnaire contained 14 questions.

Results. $63.6 \%$ (49 people) of the respondents were worried about flu, and $84.4 \%$ (65 people) were concerned about the possibility of their family members being infected. $77.9 \%$ (60 people) approve of vaccination. $51.5 \%$ (40 people) of the doctors received the vaccination in the current (2015/2016) influenza season. 18.2\% (14) of the respondents were vaccinated within the last five seasons. The respondents recommended vaccination against influenza to their families sometimes $(50.6 \%, 39)$ or frequently $(41.6 \%, 32)$. They recommended the vaccination to their patients frequently $(41.6 \%, 32)$ or sometimes $(53.2 \%$, $41)$. Only $18.2 \%$ (14) of the respondents were covered by the free vaccination program in their workplace. As many as $76.6 \%$ (59) of the doctors would recommend the vaccination more often if it were free, and $44.2 \%$ (32) would be more willing to recommend the vaccination if they received additional payment for it. When doctors were asked why they thought patients did not have themselves vaccinated, the reasons most frequently given were: patients' lack of time and awareness of the disease consequences and complications $(57.1 \%, 44)$, patients' fear of postvaccination reactions $(44.2 \%, 34)$, inconvenience associated with vaccination, including the cost of the vaccine $(42.9 \%, 33)$, patients' belief that vaccination is ineffectiveness, that the risk of infection is low, or that they do not belong to a risk infection group $(28.6 \%, 22)$ and, finally, inconvenient vaccination hours $(7.8 \%, 6)$.

Conclusions. 1. Family doctors are fully aware of the importance of vaccinating against influenza. However, this awareness is not reflected in the immunization rates among medical personnel. 2. More than half of the practitioners recommend vaccination to their patients. 3. The fear of supposed complications and financial problems are the most often indicated reasons for not being vaccinated against influenza.

Key words: vaccination, influenza, family doctor, questionnaire, health care, employees.

Fam Med Prim Care Rev 2016; 18(3): 241-243

\section{Background}

Influenza is an acute viral respiratory disease. Individuals sick with influenza act as sources of further infection. A high incidence of flu occurs every year, especially in winter. The flu virus changes its antigenic characteristics, leading to successive infections of people who have been exposed to other strains. Annual influenza vaccination is an important element of prevention [1]. According to estimates of the World Health Organisation (WHO), 5-15\% of the world's population - 330 to 1575 million people - suffers from influenza each year [2]. In Poland, the flue morbidity rate in 2013 amounted to 8,203.2 from 100,000 suspected flu infections; in 2012, the value was 3,789.0 per 100,000 [3]. In 2013 in Poland, 2.5\% of the whole population were vaccinated against influenza, most of whom were over 65 years of age (about $7.5 \%$ ), and the fewest of whom were children aged 0-4 years (about $0.6 \%$ ) [3]. The number of vaccinated people in Poland ranged from 3.4 to $3.7 \%$ from 2013 to 2015 [4]. According to WHO, vaccination is an efficient way of counteracting influenza [5]. It is both simple and safe, and its effectiveness is estimated to be 70-90\% [5]. In Poland, the proportion of vaccinated health care workers is approximately $5-6 \%$ [6].

\section{Objectives}

The aim of this study was to describe family doctors' opinions and behavior regarding vaccinations against influenza.

\section{Material and methods}

An online survey was filled out by 77 family physicians, of whom $53.5 \%$ were women. The mean age of the people surveyed was $44.6 \pm 11.7$ years. The questionnaire contained 11 questions and was based on the report Influenza vaccination among health care workers in Poland: Present and future (Tab. 1) [7]. The study was conducted from February to March, 2016. Quantitative variables were presented in the form of numbers and percentages. 


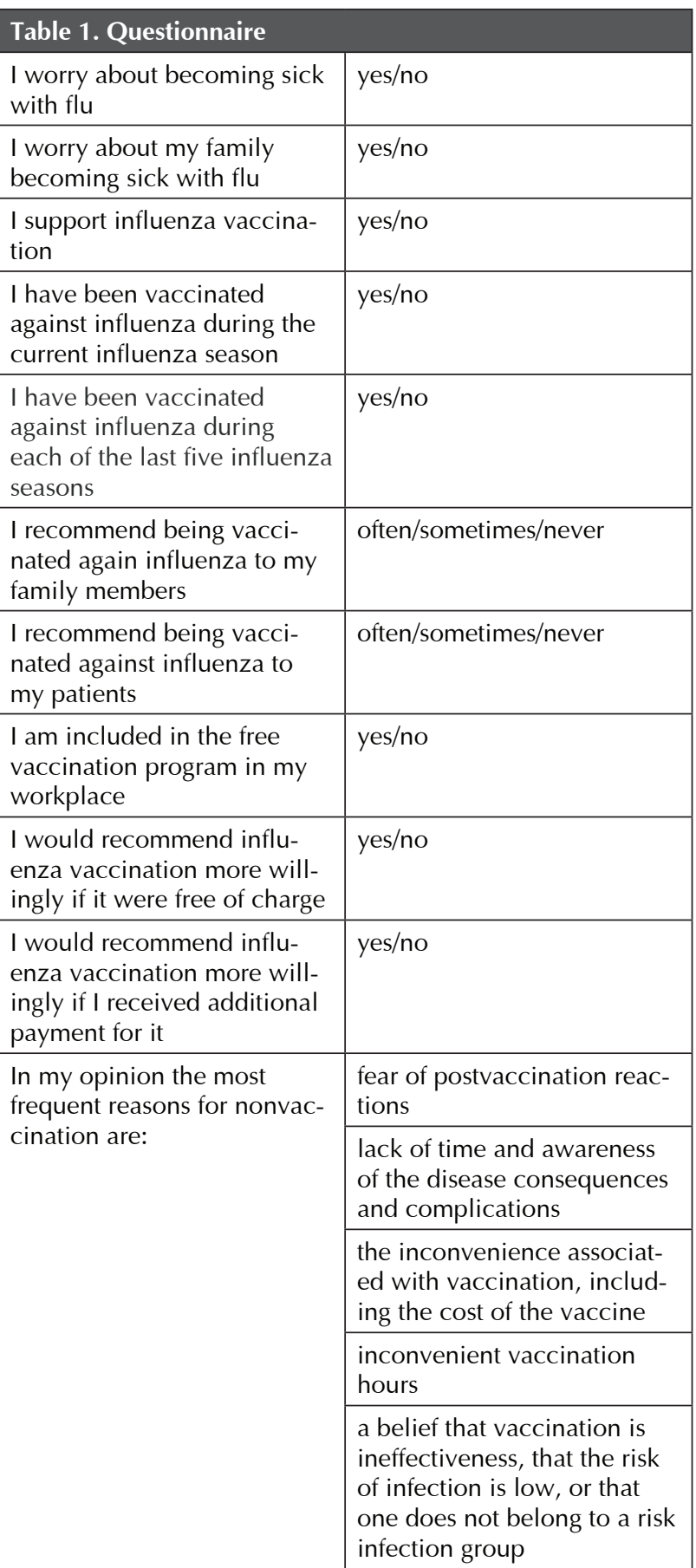

\section{Results}

$63.6 \%$ (49 people) of the respondents worried about flu, and $84.4 \%$ (65 people) were concerned about family members becoming infected. $77.9 \%$ (60 people) approve of vaccination. $51.5 \%$ (40) of the doctors had been vaccinated in the current $(2015 / 2016)$ influenza season. $18.2 \%$ (14) of the respondents had been vaccinated within the last five seasons. Vaccinations against influenza are recommended to the respondents' families sometimes $(50.6 \%, 39)$ or frequently $(41.6 \%, 32)$. The vaccination was recommended to patients frequently $(41.6 \%, 32)$ or sometimes $(53.2 \%, 41)$. Only $18.2 \%(14)$ of the respondents were included in the free vaccination program in their workplace. As many as $76.6 \%(59)$ of the doctors would recommend vaccination more often if it were free, and $44.2 \%$ (32) of respondents would be more willing to recommend vaccination if they received additional payment for it. When asked why they thought patients did not have themselves vaccinated, the reasons most frequently given by doctors were: patients' lack of time and awareness of the disease consequences and complications $(57.1 \%, 44)$, patients' fear of postvaccination reactions $(44.2 \%, 34)$, inconvenience associated with vaccination, including the cost of the vaccine $(42.9 \%, 33)$, patients' belief that vaccination is ineffectiveness, that the risk of infection is low, or that they do not belong to a risk infection group $(28.6 \%, 22)$ and, finally, inconvenient vaccination hours $(7.8 \%, 6)$.

\section{Discussion}

Influenza viral infections are respiratory droplet infections mostly transmitted by coughing or sneezing. The disease occurs suddenly and is accompanied by temperatures above $39^{\circ} \mathrm{C}$ (usually lasting for 1 to 4 days), headaches, muscle and joint pains, and a sense of general weakness. Respiratory tract ailments, such as rhinitis and tussis, may also occur. Complication-free flu usually lasts 5-6 days, and recovery usually takes at least several days after the resolution of the symptoms. Specific immunity against influenza develops 1-2 weeks after vaccination and is maintained for a period of 6-12 months. On the basis of serological test results, it is estimated that $25 \%$ of medical staff are exposed to influenza viruses every year [8]. According to the result of one study, nearly $75 \%$ of doctors admit that they perform their professional duties with symptoms that suggest current respiratory tract infection [8].

This paper presents the results of an online survey of family doctors regarding their perception and practice of influenza vaccination. Medical personnel's awareness of the need for immunization against influenza appears to be high, as $77.9 \%(60)$ of the respondents are support vaccination. However, little more than half $(51.5 \%, 40)$ of the doctors were themselves vaccinated in the current influenza season, and only $18.2 \%$ (14) regularly received the vaccine over the past 5 years. Of the 14 people vaccinated during each of the five previous epidemiological seasons, 13 were not covered by the free vaccination program in their workplace, whereas of the 14 individuals covered by the free vaccination program in their workplace, only one received the vaccination during each of the five previous epidemiological seasons. These differences are not statistically significant $\left(p=0.236\right.$ in Pearson's chi-squared test $\left.\left(\chi^{2}\right)\right)$. Family doctors recommend vaccination to their families and patients with similar frequency. Despite the fact that only $7 \%$ of doctors never recommend vaccines, the number of vaccinated health care workers and patients remains very low in Poland [6]. In the United States, the number oscillates between $20 \%$ and $80 \%$ (with the mean around $40-50 \%$ ) [8]. Family doctors and pediatricians receive the vaccine most often, while surgeons received it most rarely. Data gathered by the Center for Disease Control and Prevention (CDC) indicate that medical personnel working in hospitals and people over 60 years of age were vaccinated most frequently [9]. The reasons for this situation can be explained in different ways, but the economic aspect is most frequently mentioned in the survey. Only $18.2 \%$ of physicians are covered by the free vaccination program in their workplace. Free vaccines for patients would make as many as $76.6 \%$ of the physicians recommend this type of protection. Additional remuneration would create a significant incentive to convince patients of the need for immunization.

Vaccinations have been recommended to medical personnel in the US and in over 40 other countries, including Poland, since 1994 [10]. Such vaccinations are important, as medical personnel encounter many patients. Any infection is associated with an increased risk of infection for patients and other members of staff. Sickness results in absence 
from work and disturbs the functioning of the medical team. A study by Fiore et al. showed that vaccination of personnel contributed a drop of $28 \%$ in work absences [11].

Influenza infection can lead to increased mortality among the elderly, nursing home residents, and hospitals patients. Vaccination of medical personnel indirectly reduces the infection-related risk of complications or death among people at risk of infection, such as pregnant women, infants, and the elderly [8]. Annual vaccination reduces influenza-related mortality by $41 \%$ [12], or by as much as $75 \%$ among those who are vaccinated each year [11]. In a study conducted in long-term care homes in the UK, where $61 \%$ of the staff had been vaccinated, the proportion of deaths among patients decreased from $17 \%$ to $10 \%$ [13]. Interestingly, vaccinations of the patients themselves did not affect mortality reduction in a statistically significant way [13]. These data demonstrate that people who regularly receive vaccinations each year obtain the highest degree of protection. A study by Ahmed et al. showed that vaccination of health care workers was associated with a reduced risk of death from all causes by $29 \%$, and from influenza by $42 \%$ [14]. However, it is worrying that, according to the present study, $22.1 \%$ of physicians are against vaccination.
In recent years, there have been many voices against the use of vaccination. Some people do not vaccinate children for fear of adverse outcomes. Another group believes that childhood vaccines may be used, because they are administered at most several times in life, rather than annually, as in the case of influenza.

Due to the possible serious complications associated with influenza infection, further action is needed to promote knowledge of infection-related dangers, postinfluenza complications, and economic and social threats.

\section{Conclusions}

1. Family doctors are fully aware of the importance of vaccinating against influenza. However, this awareness is not reflected in the immunization rates among medical personnel.

2. More than half of practitioners recommend vaccination to their patients.

3. Fear of the occurrence of supposed complications and financial problems are the most frequently indicated reasons for not becoming vaccinated.

Source of funding: This work was funded by the authors' resources. Conflict of interest: The authors declare no conflict of interests.

\section{References}

1. Talbot TR, Talbot HK. Influenza prevention update: examining common arguments against influenza vaccination. JAMA 2013; 309(9): 881-882.

2. Fiore $\mathrm{AE}$, Uyeki TM, Broder $\mathrm{K}$, et al. Prevention and control of influenza: recommendations of the Advisory Committee on Immunization Practices (ACIP). MMWR 2010; 59(RR-8): 1-68.

3. Jackowska T, Sapała-Smoczyńska A. Szczepienia przeciw grypie w sezonie 2014-2015. Post Nauk Med 2014; XXVII(10B): $19-22$.

4. Blank P, Falup-Pecurariu O, Kassianos G, et al. Szczepienia przeciw grypie: podstawowe fakty dla lekarzy pierwszego kontaktu w Europie. Synteza opracowana przez ekspertów europejskich na podstawie zaleceń krajowych i najlepszych praktyk w Wielkiej Brytanii i Holandii. Warszawa: Fundacja Nadzieja dla Zdrowia; 2016.

5. Brydak LB. Grypa znana od stuleci - nadal groźna. Fam Med Prim Care Rev 2014; 16(2): 181-184.

6. Kuchar E, Nitsch-Osuch A. Bezpieczna Placówka Medyczna, czyli jak skutecznie ograniczać transmisję wirusa grypy. Warszawa: Instytut Oświaty Zdrowotnej Fundacja Haliny Osińskiej; 2014.

7. Antczak A, Ciszewski A, Jahnz-Różyk K, et al. Szczepienia przeciw grypie wśród pracowników ochrony zdrowia w Polsce - teraźniejszość i perspektywy. Warszawa: Instytut Oświaty Zdrowotnej Fundacja Haliny Osińskiej; 2013.

8. Nitsch-Osuch A, Brydak LB. Szczepienia przeciw grypie u personelu medycznego. Med Pr 2013; 64(1): 119-129.

9. Centers for Disease Control and Prevention (CDC). Prevention and control of seasonal influenza with vaccines. Recommendations of the Advisory Committee on Immunization Practices - United States, 2013-2014. MMWR Recomm Rep 2013; 6 2(RR-07): 1-44.

10. The macro-epidemiology of influenza vaccination in 56 countries, 1997-2003. Vaccine 2005; 23(44): 5133-5143.

11. Fiore AE, Shay DK, Broder K, et al. Prevention and control of seasonal influenza with vaccines: recommendations of the Advisory Committee on Immunization Practices (ACIP), 2009. MMWR Recomm Rep 2009; 58(RR-8): 1-52.

12. Ahmed AE, Nicholson KG, Nguyen-Van-Tam JS. Reduction in mortality associated with influenza vaccine during 1989-90 epidemic. Lancet 1995; 346(8975): 591-595.

13. Potter J, Stott DJ, Roberts MA, et al. Influenza vaccination of health care workers in long-term-care hospitals reduce the mortality of elderly patients. J Infect Dis 1997; 175(1): 1-6.

14. Ahmed F, Lindley MC, Allred N, et al. Effect of influenza vaccination of healthcare personnel on morbidity and mortality among patients: Systematic review and grading of evidence. Clin Infect Dis 2014; 58(1): 50-57.

Address for correspondence:

Piotr Gutknecht, MD, PhD

Katedra Medycyny Rodzinnej GUM

ul. Dębinki 2

80-211 Gdańsk

Polska

Tel.: +48 58 349-15-75

E-mail: pgutknecht@gumed.edu.pl

Received: 31.03.2016

Revised: 09.05.2016

Accepted: 31.05.2016 